\title{
KEEFEKTIFAN MODEL SNOWBALL THROWING BERBANTU MEDIA WAYANG KERTAS TERHADAP HASIL BELAJAR SISWA TEMA 7 INDAHNYA KERAGAMAN
}

\author{
Dwy Afita Sari ${ }^{1}$, Sri Suneki ${ }^{2}$, Veryliana Purnamasari ${ }^{3}$ \\ 1,2,3 PGSD Fakultas IImu Pendidikan \\ Universitas PGRI Semarang
}

email : Afita275@gmail.com, neegitha@gmail.com,verylianapurnamasari@gmail.com,

\begin{abstract}
Abstrak
Latar belakang yang mendasari penelitian ini adalah peneliti ingin mengetahui keefektifan model Snowball Throwing brebantu media Wayang Kertas terhadap hasil belajar siswa kelas IV SD Negeri 2 Kuwu. Jenis penelitian ini adalah penelitian kuantitatif dalam bentuk pre-eksperimental design dengan bentuk One-Group-Pretest-Posttest Design yaitu hanya satu kelas yang digunakan sebagai subyek penelitian. Teknik pengumpulan data dalam penelitian ini menggunakan tes, wawancara, observasi, dan dokumentasi. Pada penelitian ini nilai rata-rata pretest sebesar 66,4 sedangkan rata-rata nilai posttest sebesar 75,4 . Teknik analisis data terdiri dari uji normalitas, uji ketuntasan belajar dan uji t. Analisis data menggunakan uji $t$ diperoleh hasil 14,466 lebih besar dari $t_{\text {tabel }}$ yaitu 2,026 sehingga $\mathrm{H}_{0}$ ditolak dan $\mathrm{H}_{\mathrm{a}}$ diterima artinya hasil penelitian menunjukkan bahwa penggunaan model Snowball Throwing berbantu media Wayang Kertas efektif terhadap hasil belajar siswa kelas IV SD Negeri 2 Kuwu Tema Indahnya Keragaman di Negeriku Subtema Keragaman Suku Bangsa dan Agama di Negeriku.
\end{abstract}

Kata kunci: Snowball Throwing, Wayang Kertas, Hasil Belajar

\begin{abstract}
The background that underlies this research was that researchers want to know the effectiviness of the Snowball Throwing model assisted by Pupet Paper media on the learning outcomes of fourth grades students at SD Negeri 2 Kuwu. This type of research is quantitative research in the form of preeksperimental design in the form of the One-Group-Pretest-Posttest Design that is only one class that used as the research subject. Data collection techniques in this study are test, interviews, observation, and documentation. In this study the average pretets value was 66,4 while the average posttest value was 75,4. Data analysis techniques consisted of normality test, learning completeness test and test. Data analysis using $t$ test result was 14,466 bigger than $\mathrm{t}$ table that was 2,026 so that $\mathrm{H} 0$ is rejected and $\mathrm{Ha}$ is accepted this means that the result of the study show that the use of Snowball Throwing models assisted by Puppet Paper media was effective against the learning outcomes of fourth grade students of SD Negeri 2 Kuwu Theme of Beautiful Divesity in My Country Subtem of Ethnic Diversity and Religion in My Country.
\end{abstract}

Keywords: Snowball Throwing, Paper Puppet, Learning Outcomes 


\section{Pendahuluan}

Pendidikan merupakan salah satu usaha setiap bangsa untuk meningkatkan kualitas sumber daya manusia sehingga membantu memperlancar pelaksanaan pembangunan nasional Indonesia. Pendidikan juga merupakan suatu kebutuhan manusia yang sangat penting, karena dengan pendidikan dapat menciptakan manusia yang berkualitas dan berkarakter yang memiliki wawasan yang luas. Usaha pendidikan ini ditujukan untuk mengembangkan cipta, rasa, dan karsa yang ada sehingga setiap manusia diharapkan mampu menghadapi tantangan sesuai dengan tuntutan perubahan kehidupan lokal, nasional, maupun kehidupan global.

Penjelasan dalam UU No 20 Tahun 2003 tentang sistem pendidikan nasional, menyatakan bahwa pendidikan berfungsi untuk mengembangkan kemampuan serta membentuk watak dan beradaban bangsa yang bermartabat dalam rangka mencerdaskan kehidupan bangsa, hal ini bertujuan untuk mengembangkan potensi yang dimiliki peserta didik agar menjadi manusia yang beriman, bertakwa kepada Tuhan Yang Maha Esa, berakhlak mulia, sehat, berlimu, cakap, kreatif, mandiri, dan menjadi warga Negara yang demokratis serta bertanggung jawab.

Tujuan pendidikan akan tercapai apabila terdapat peran aktif dari komponen-komponen pendidikan yaitu tujuan pendidikan, peserta didik, pendidik, isi pendidikan, metode pendidikan, alat pendidikan, dan lingkungan pendidikan. Guru memiliki peran penting dalam mewujudkan tujuan pendidikan nasional, karena guru yang menentukan keberhasilan siswa dalam pembelajaran.

Berdasarkan teori belajar bermakna dari David Paul Ausubel dalam Dahar (2011: 95) hendaknya guru memiliki teknik dan model khusus agar pembelajaran lebih bermakna dan menyenangkan, sehingga pembelajaran tidak cenderung monoton dan membosankan. Berdasarkan observasi awal proses belajar mengajar di kelas IV SD Negeri 2 Kuwu, hasil yang didapatkan yaitu metode pembelajaran yang diterapkan guru kurang bervariatif dan guru hingga saat ini masih menggunakan pembelajaran konvensional yaitu ceramah, sehingga berdampak pada kurangnya minat siswa dalam pembelajaran dan pembelajaran berlangsung kurang maksimal.

Menurut Ni Nyoman Parwati (2018: 36) dalam bukunya Belajar dan Pembelajaran, faktor-faktor yang mempengaruhi belajar dibedakan atas dua kategori, yaitu faktor intern dan faktor ekstern.(1) Faktor Internal (dalam) meliputi kondisi kesehatan dan kebugaran fisik, serta kondisi panca inderanya terutama penglihatan dan pendengaran kecerdasan siswa, sikap, minat, bakat, intelegensi, motivasi, dan kemampuan-kemampuan kognitif seperti kemampuan persepsi, ingatan, bepikir, dan kemampuan dasar yang dimiliki (2) Faktor Eksternal (luar), faktor luar terdiri dari faktor keluarga, faktor sekolah dan faktor masyarakat. Pada faktor keluarga siswa akan menerima pengaruh dari keluarga berupa cara orang tua mendidik, relasi antara anggota keluarga, suasana rumah tangga, keadaan ekonomi keluarga, pengertian orang tua, dan latar belakang kebudayaan. Pada Faktor Sekolah yang mempengaruhi hasil belajar siswa yaitu metode mengajar yang diberikan oleh guru, kurikulum, relasi guru dengan siswa, relasi siswa dengan siswa, disiplin sekolah, alat pelajaran, waktu sekolah, standar pelajaran di atas ukuran, keadaan gedung, metode belajar, tugas rumah.Sedangkan pada faktor masyarakat seperti kegiatan siswa dalam masyarakat, media massa, teman bergaul, dan bentuk kehidupan masyarakat.

Menurut Schunk (2012: 2) belajar merupakan suatu aktivitas yang melibatkan pemerolehan dan pemodifikasian pengetahuan, ketrampilan, strategi, keyakinan, perbuatan, dan tingkah laku. Schunk menambahkan bahwa ada tiga rumusan yang dapat disebut sebagai inti dari belajar. Ketiga hal tersebut meliputi belajar melibatkan adanya perubahan, hasil dari belajar dapat bertahan sepanjang masa, dan belajar diperoleh sebagai hasil belajar. Belajar adalah suatu proses kegiatan untuk memperoleh pengetahuan, ketrampilan, perbuatan, dan tingkah laku dimana dengan belajar dapat menyebabkan suatu perubahan individu dan dilalui berdasarkan pengelaman yang telah dilakukan 
Hasil belajar adalah suatu hasil yang diperoleh siswa dalam proses belajar dan pembelajaran yang telah dilakukannya dalam beberapa kurun waktu tertentu dan telah melibatkan aspek kognitif, afektif maupun psikomotorik yang dinyatakan dalam symbol, huruf maupun kalimat. Untuk memperoleh hasil belajar hendaknya memerlukan alat yang digunakan untuk mengukur hasil belajar siswa alat tersebut bisa berupa soal evaluasi atau penilaian setelah melakukan proses pembelajaran.

Menurut Nawawi dalam (Susanto, 2013: 5) yang menyatakan bahwa hasil belajar dapat diartikan sebagai tingkat keberhasilan siswa dalam mempelajari materi pelajaran di sekolah yang dinyatakan dalam skor yang diperoleh dari hasil tes mengenal sejumlah materi pelajaran tertentu. Jadi pendapat ini dapat dinyatakan bahwa hasil belajar tersebut ditentukan oleh guru dengan diberikannya sebuah tes soal dari materi yang sudah diajaarkan. Jadi baik atau rendahnya nilai hasil belajar siswa juga ditentukan oleh metode guru dalam proses pembelajaran. Oleh karena itu, guru perlu menerapkan model pembelajaran yang relevan dengan bantuan media yang kreatif dan inovatif agar tercipta pembelajaran yang yang lebih bermakna dan efektif.

Menyoroti masalah kreativitas, pembelajaran membutuhkan guru yang kreatif agar suasana pembelajaran menjadi lebih menarik dan inovatif. Penerapan model dan media pembelajaran dapat menumbuhkan minat siswa dalam belajar dan menjadikan suasana belajar yang menarik. Menurut Jumanta Hamdayama dalam buku Model Dan Metode Pembelajaran Kreatif dan Berkarakter (2015: 64), model pembelajaran kooperatif merupakan model pembelajaran dengan menggunakan sistem pengelompokan/ tim kecil, yaitu antara empat sampai enam orang yang memiliki latar belakang kemampuan akademik, jenis kelamin, rasa tau suku yang berbeda. Sitem penilaian dilakukan terhadap kelompok

Sedangkan menurut Criticos dalam Daryanto (2016 : 4) mengatakan bahwa media pembelajaran adalah salah satu komponen komunikasi, yaitu sebagai pembawa pesan dari komunikator menuju komunikan. Berdasarkan definisi tersebut, dapat dikatakan bahwa media pembelajaran merupakan sarana perantara dalam proses pembelajaran.

Berdasarkan hasil wawancara dengan guru kelas IV SD Negeri 2 Kuwu yaitu ibu Dyah Ayu Rahmawati, S.Pd., bahwa siswa di SD Negeri 2 Kuwu khususnya kelas IV mengalami hasil belajar yang rendah karena antusias siswa dalam proses pembelajaran kurang, siswa mudah merasa bosan dan kurang konsentrasi karena proses pembelajaran yang dirasa menjenuhkan terutama pembelajaran tematik. Permasalahan yang terjadi kerena guru hanya menggunakan metode atau model pembelajaran yang kurang bervariatif.

Berdasarkan permasalahan tersebut, diperlukan adanya solusi dalam mengatasi minat belajar siswa yaitu dengan menerapkan model dan media pembelajaran yang kereatif dan inovatif terutama dalam pembelajaran tematik. Menurut Trianto (2013:139) Pembelajaran tematik adalah pembelajaran terpadu yang menggunakan tema untuk mengaitkan beberapa mata pelajaran sehingga dapat memberikan pengalaman belajar yang bermakna kepada peserta didik. Salah satu model pembelajaran yang dapat menumbuhkan minat siswa dalam belajar yaitu penerapan model pembelajaran Snowball Throwing. Model pembelajaran Snowball Throwing diharapkan dapat menciptakan suasana yang menyenangkan dalam proses pembelajaran dan menciptakan semangat siswa dalam belajar.

Jumanta Hamdayama (2015:157) dalam buku Model dan Metode Pembelajaran Kreatif dan Berkarakter, menyatakan bahwa prinsip pembelajaran dengan metode Snowball Throwing termuat di dalam prinsip pendekatan kooperatif yang didasarkan pada lima prinsip, yaitu prinsip belajar siswa aktif (student active learning), belajar kerja sama (cooperative learning), pembelajaran partisipatorik, mengajar reaktif (reactive learning), dan pembelejaran yang menyenangkan (joyfull learning). Snowball Throwing merupakan suatu pembelajaran yang melibatkan siswa untuk aktif dan kreattif, dan mengajarkan siswa untuk saling bekerja sama sehingga pembelajaran berlangsung menyenangkan.

menurut Aris (2014: 176) Model Snowball Throwing mempunyai kelebihan yang semuanya melibatkan dan keikutsertaan siswa dalam pembelajaran. Kelebihan dari model Snowball Throwing yaitu : 1) Suasana pembelajaran menjadi menyenangkan karena siswa seperti bermain dengan melempar bola kertas kepada siswa lain. 2) Siswa mendapat 
kesempatan untuk mengembangkan kemampuan berpikir karena diberi kesempatan untuk membuat soal dan diberikan kepada siswa lain. 3) Membuat siswa siap dengan berbagai kemungkinan karena siswa tidak tahu soal yang dibuat temannya seperti apa. 4) Siswa telibat aktif dalam pembelajaran. 5) Pembelajaran menjadi lebih efektif. 6) Aspek kognitif, afektif, dan psikomotorik dapat tercapai.

Di samping terdapat kelebihan tentu saja model Snowball Throwing juga mempunyai kelemahan. Kelemahan dari model Snowball Throwing menurut Aris (2014: 176) yaitu: 1) Sangat bergantung pada kemampuan siswa dalam memahami materi sehingga apa saja yang dikuasai siswa hanya sedikit. Hal ini dapat dilihat dari soal yang dubuat siswa biasanya hanya seputar materi yang suah dijelaskan atau seperti contoh soal yang telah diberikan. 2) Ketua kelompok yang tidak mampu menjelaskan dengan baik tentu pengahambat bagi anggota lain untuk memahami nateri sehingga diperlukan waktu yang tidak sedikit untuk siswa mendiskusikan materi pelajaran. 3) Memerlukan waktu panjang. 4) Murid yang nakal cenderung untuk berbuat onar. 5) Kelas sering kali gaduh karena kelompok dibuat oleh murid.

Dalam pembelajaran Snowball Throwing siswa diajak untuk berkomunikasi dengan baik dengan kelompoknya, hal ini terlihat pada saat menjawab pertanyaan yang didapat dilakukan dengan berdiskusi kelompok. Dari uraian di atas dapat disimpulkan bahwa pembelajaran Snowball Throwing tidak hanya meningkatkan kemampuan siswa dari segi akademik tetapi juga mengembangkan keterampilan bersosialisasi dengan lingkungan sekitarnya.

Yuliati (2015) menyatakan bahwa penerapan metode pembelajaran dengan menggunakan metode snowball throwing telah memperlihatkan peningkatan persentase ketuntasan hasil belajar siswa pada tahap siklus. Berdasarkan hasil tes awal dan akhir dari kedua siklus, maka dapat disimpulkan bahwa seluruh kegiatan perbaikan pengajaran ini semuanya telah menunjukkan keberhasilan dalam memberi pemahaman kepada para siswa secara tepat dan akurat.

Manfaat yang secara langsung terlihat adalah sedikit jumlah para siswa yang belajarnya tidak tuntas. Ini disebabkan karena penerapan metode pembelajaran dengan menggunakan model snowball throwing telah memperlihatkan peningkatan persentase siswa yang aktif dalam proses pembelajaran pada setiap siklus.

Pembelajaran tipe Snowball Throwing dapat meningkatkan hasil belajar. Gustomo (2015) Peningkatan hasil belajar menggunakan model pembelajaran kooperatif tipe Snowball Throwing lebih besar dibandingkan dengan hasil belajar menggunakan model pembelajaran konvensional. Hal ini sejalan dengan penelitian Ramlah (2017) yang menyatakan bahwa Berdasarkan hasil analisis dan pembahasan dapat disimpulkan bahwa penerapan metode pembelajaran kooperatif tipe snowball throwing dapat meningkatkan hasil belajar siswa. Keberhasilan ini disebabkan dengan penerapan metode pembelajaran kooperatif tipe snowball throwing siswa menjadi lebih aktif yang berarti siswa cenderung positif dalam mengikuti proses belajar mengajar yang diberikan oleh guru maupun dalam melakukan diskusi di dalam dan antar kelompoknya.

Penggunaan model pembelajaran Snowball Throwing dapat diinovasi lagi dengan berbantu media pembelajaran yang menarik, salah satu media pembelajaran yang keartif dan inovatif yaitu media wayang kertas. Menurut Hujair AH Sanaky dalam buku Media Pembelajaran Interaktif-Inovatif (2013 : 5) Substansi dari media pembelajaran adalah : (1) bentuk saluran, yang digunakan untuk menyalurkan pesan, informasi atau bahan pelajaran kepada penerima pesan atau pembelajar; (2) berbagai jenis komponen dalam lingkungan pembelajar yang dapat merangsang pembelajar untuk belajar; (3) bentuk alat fisik yang dapat menyajikan pesan serta merangsang pembelajar untuk belajar; (4) bentuk-bentuk komunikasi dan metode yang dapat merangsang pembelajar untuk belajar, baik cetak maupun audio, visual, dan audio-visual.

Media Wayang Kertas merupakan sebuah media permainan, dimana terdapat simulasi atau pemeragaan dalam memainkan wayang kertas. Media wayang kertas adalah alat bantu pembelajaran yang digunakan guru dalam menyampaikan materi yang terbuat dari kertas yang berbentuk gambar kartun atau gambar asli yang diberi tangkai untuk digerakkan. Wayang yang digunakan bisa disesuaikan dengan tema materi. 
Penggunaan model Snowball Throwing telah di uji coba oleh Putri Adriliyani (2017) yang menunjukkan bahwa Model Pembelajaran Snowball Throwing Berbantu Media Roda Putar Efektif Terhadap Hasil Belajar IPS Kelas III Hal tersebut terlihat dalam abstrak yang menunjukkan bahwa terdapat perbedaan hasil nilai posstest lebih tinggi pada kelas eksperimen yang menggunakan model pembelajaran Snowball Throwing berbantu media roda putar dibandingkan dengan kelas kontrol yang menggunakan pembelajaran secara konvensional. Selain itu Siti Irsanti (2018) menunjukkan bahwa metode bercerita berbantu wayang kertas sangat efektif dan hasil belajar pada pembelajaran tematik siswa kelas III SD Negeri Peterongan dapat meningkat. Hal tersebut terlihat dalam abstrak yang menunjukkan bahwa terdapat perbedaan hasil belajar sebelum dan sesudah diterapkkannya metode bercerita berbantu media wayang kertas.

Berdasarkan uraian tersebut, maka diperlukan penelitian untuk menguji keefektifan model Snowball Throwing berbantu media Wayang Kertas terhadap hasil belajar siswa kelas IV SD Negeri 2 Kuwu.

\section{Metode}

Peneliti melakukan penelitian di SD Negeri 2 Kuwu, Kecamatan Kradenan, Kabupaten Grobogan, Jawa Tengah. Dalam penelitian ini yang menjadi variabel bebas atau variabel $X$ adalah model Snowball Throwing berbantu media Wayang Kertas. Sedangkan variabel terikat atau variabel $Y$ yaitu hasil belajar sisw kelas IV SD Negeri 2 Kuwu. Penelitian ini dilakukan dengan menggunakan Pre Eksperimental Design bentuk One Group Pretest-Posttest Design. Pada desain ini terdapat pretest, sebelum diberi perlakuan. Dengan demikian hasil perlakuan dapat diketahui lebih akurat, karena dapat membandingkan dengan keadaan sebelum diberi perlakuan (Sugiyono, 2016: 73-75).

Subjek penelitian ini adalah siswa kelas IV SD Negeri 2 Kuwu semester 2 tahun ajaran 2018/2019. Data dalam penelitian ini digunakan untuk mengetahui pengaruh model pembelajaran Snowball Throwing berbantu media Wayang Kertas terhadap hasil belajar siswa kelas IV SD Negeri 2 Kuwu Tema Indahnya Keragaman di Negeriku dengan jumlah 19 siswa. Teknik pengumpulan data yang digunakan dalam penelitian adalah metode tes, metode observasi, metode wawancara dan metode dokumentasi. Dalam metode wawancara dilakukan bersama wali kelas IV SD Negeri 2 Kuwu yaitu Ibu Dyah Ayu Rahmawati S.Pd. untuk mengetahui kondisi awal peserta didik. Pengumpulan data dengan metode tes yang digunakan peneliti yaitu pretest dan posttest dengan bentuk pilihan ganda. Pretest digunakan peneliti untuk mengetahui kondisi awal peserta didik sebelum diberi perlakuan dan posttest digunakan stelah diberi perlakuan model Snowball Throwing berbantu media Wayang Kertas. Sedangkan metode dokumentasi berupa arsip nilai siswa, foto-foto pelaksanaan proses pembelajaran yang dilakukan di SD Negeri 2 Kuwu. Uji yang digunakan dalam penelitian ini yaitu: Uji Normalitas, Uji Hipotesis, dan Uji t.

\section{Hasil Dan Pembahasan}

Jenis penelitian ini adalah penelitian kuantitatif dalam bentuk pre-eksperimental design dengan bentuk One-Group-Pretest-Posttest Design. Pretest merupakan tes awal untuk mengetahui kemampuan awal siswa dan diberikan sebelum peneliti memberikan materi dengan menggunakan model Snowball Throwing dan media Wayang Kertas. Posttest merupakan tes akhir siswa setelah diberi perlakuan dengan menggunakan model Snowball Throwing dan media Wayang Kertas.

Berdasarkan hasil perhitungan penelitian yang dilakukan di SD Negeri 2 Kuwu kelas IV pada semester 2 tahun ajaran 2018/2019, diperoleh data yang disajikan dalam Tabel 1 
Tabel 1 Hasil Pretest dan Postets

\begin{tabular}{|c|c|c|}
\hline Keterangan & Pretest & Postetst \\
\hline Nilai Terendah & 46 & 53 \\
\hline Nilai Tertinggi & 83 & 93 \\
\hline Rata-rata & 66,4 & 75,4 \\
\hline Selisih rata-rata pretest dan postets & & \\
\hline
\end{tabular}

Berdasarkan pada Tabel 1 diperoleh hasil belajar pretest dengan nilai terendah sebesar 46 dan nilai tertinggi sebesar 83 dan diperoleh nilai rata-rata pada hasil belajar pretest sebesar 66,4. Pada hasil belajar posttest setelah menggunakan model pembelajaran Snowball Throwing berbantu media Wayang Kertas maka diperoleh nilai terendah sebesar 53 dan nilai tertinggi sebesar 93 dengan nilai rata-rata sebesar 75,4 . Sehingga selisih nilai pretest dan posttest adalah 9 .

Berdasarkan hasil analisis data dalam penelitian yang diperoleh dengan menggunakan Uji normalitas yaitu uji normlitas awal (presetst) dan uji normalitas akhir (posttest). Uji normalitas data menggunakan uji liliefors. Hasil perhitungan pretest dan posttest dapat dilihat pada gambar tabel sebagai berikut :

Tabel 2 Tabel Perhitungan Uji Normalitas Awal

\begin{tabular}{llllll}
\hline Analisis data & $\mathrm{n}$ & $\mathrm{L}_{\text {hitung }}$ & $\mathrm{L}_{\text {tabel }}$ & Kriteria & Simpulan \\
\hline Pretest & 19 & 0,077 & 0,195 & $\mathrm{~L}_{\text {hitung }}<\mathrm{L}_{\text {tabel }}$ & $\begin{array}{l}\mathrm{H}_{0} \text { diterima } \\
\text { (berdistribusi normal) }\end{array}$ \\
\hline
\end{tabular}

Berdasarkan gambar tabel 2 tersebut hasil perhitungan nilai pretest soal dengan jumlah n sebanyak Sembilan belas dan taraf signigfikan 0,05 diperoleh $L_{\text {abel }}$ sebesar 0,195 dan $L_{0}$ atau $L_{\text {hitung }}$ sebesar 0,077 . Karena $L_{0}<L_{\text {tabel }}$ yaitu $0,077<0,195$ maka $H_{0}$ diterima. Jadi dapat disimpulkan bahwa sampel berdistribusi normal.

Tabel 3 Tabel Perhitungan Uji Normalitas Akhir

\begin{tabular}{cccccc}
\hline Analisis data & $\mathrm{n}$ & $\mathrm{L}_{\text {hitung }}$ & $\mathrm{L}_{\text {tabel }}$ & Kriteria & Simpulan \\
\hline Posttest & 19 & 0,0977 & 0,195 & $\mathrm{~L}_{\text {hitung }}<\mathrm{L}_{\text {tabel }}$ & $\begin{array}{c}\mathrm{H}_{0} \text { diterima } \\
\text { (berdistribusi normal) }\end{array}$ \\
\hline
\end{tabular}

Berdasarkan gambar Tabel 3 tersebut hasil perhitungan nilai posttest dengan jumlah $\mathrm{n}$ sebanyak sembilan belas dan taraf signifikan 0,05 diperoleh $L_{\text {tabe }}$ sebesar 0,195 dan $L_{0}$ atau $L_{\text {nitung }}$ sebesar 0,0977. Karena $\mathrm{L}_{0}<\mathrm{L}_{\text {tabel }}$ yaitu 0,0977 $<0,195$ maka $\mathrm{H}_{0}$ diterima. Jadi dapat disimpulkan bahwa sampel berdistribusi normal.

Hasil penelitian menunjukkan bahwa ada peningkatan yang signifikan anatar nilai pretest dan nilai posttest. Jadi dapat disimpulkan bahwa pembelajaran dengan model pembelajaran Snowball Throwing yang berbantu media Wayang Kertas efektif untuk meningkatkan hasil belajar siswa. Penelitian ini dapat dikatakan efektif jika data yang sudah diperoleh hasil belajar siswa mengalami peningkatan ketika diterapkan model pembelajaran Snowball Throwing.

Ciri utama model Snowball Throwing yaitu siswa membuat sebuah pertanyaan di selembar kertas dan membentuknya seperti bola, kemudian bola tersebut dilempar ke murid yang lain. Kegiatan melempar bola ini akan membuat kelompok menjadi dinamis karena kegiatan siswa tidak hanya berpikir, menulis, dan berbicara, akan tetapi mereka juga melakukan aktifitas fisik (Jumanta Hamdaya, 2015:158). Dan penerapan media Wayang Kertas menurut Rizki Oktaviani dan Agus Wiyanto (2014: 65) yaitu media Wayang Kertas digunakan sebagai media pembelajaran yang menyenangkan. Para guru mulai kreatif dalam menciptakan 
suatu media-media baru untuk menunjang keberhasilan dalam pembelajaran dan mendapat suatu tangapan yang baik dari siswa

Berdasarkan teori tersebut, pada penelitian menggunakan model Snowball Throwing berbantu media Wayang Kertas ini, mampu menumbuhkan minat siswa untuk belajar. Hal ini terlihat dari semangat dan antusias siswa dalam mengikuti pembelajaran, dibuktikan melalu nilai rata-rata siswa sebelum diberi perlakuan (pretest) yaitu sebesar 66,4 dan nilai rata-rata setelah diberi perlakuan (posttest) yaitu sebesar 75,4.Selain nilai hasil belajar pretest dan posttest, peneliti juga menilai pasa aspek afektif dan psikhomotorik. Hasil rata-rata aspek afektif dan pskhomotorik dapat dilihat pada tabel sebagai berikut:

Tabel 4 Hasil Nilai Afektif

$$
\begin{array}{lll}
\text { Pertemuan } 1 & \text { Pertemuan } 2 & \text { Pertemuan } 3
\end{array}
$$

\begin{tabular}{lccc} 
Tertinggi & 92 & 92 & 100 \\
Terendah & 67 & 67 & 75 \\
\hline Rata-rata & 78,26 & 83,26 & 88,57
\end{tabular}

Dari data yang tertera pada Tabel 4, dapat terlihat bahwa penilaian afektif dari pertemuan 1 hingga pertemuan 3 meningkat sebanyak 84,05 sehingga dapat dikatakan penilaian afektif terjadi kenaikan. Dibuktikan dengan nilai rata-rata kelas pada pertemuan 1 adalah 78,26 pada pertemuan 2 rata-rata kelas adalah 83,23 dan pada pertemuan 3 rata-rata kelas adalah 88,57. Setiap pertemuan terdapat beberapa aspek yang menonjol dibuktikan dengan jumlah skor tertinggi yang dicapai pada aspek tertentu yaitu pada pertemuan 1 hingga pertemuan 3 aspek teliti memiliki skor yang tinggi dibuktikan pada perolehan skor aspek teliti pada pertemuan 1 mendapatkan skor 69, selanjutnya pada pertemuan ke 2 meningkat menjadi 70 , hingga pada pertemuan ke 3 skor perolehan aspek teliti masih unggul yaitu memperoleh skor 74. Jadi dari hasil diatas aspek teliti merupakan aspek yang memiliki nilai paling menonjol pada setiap pertemuannya karena mengalami peningkatan terus menerus dan memiliki skor paling tertinggi dibanding dengan aspek yang lain seperti tanggung jawab, dan percaya diri. Aspek tanggung jawab dan juga percaya diri memang mengalami peningkatan skor perolehan pada setiap pertemuannya, namun skor yang di peroleh tetap di bawah dari perolehan skor aspek teliti. Sehingga dapat disimpulkan bahwa aspek teliti merupakan aspek yang paling menonjol pada setiap pertemuannya.

Tabel 5 Hasil Nilai Psikomotorik

\begin{tabular}{rccc}
\hline & Pertemuan 1 & Pertemuan 2 & Pertemuan 3 \\
\hline Tertinggi & 3 & 3 & 4 \\
\hline Terendah & 2 & 2 & 3 \\
\hline Rata-rata & 2,52 & 2,68 & 3,1 \\
\hline
\end{tabular}

Berdasarkan Tabel 5 pada pertemuan 1 rata-rata nilai kelas adalah 2,52. Pada pertemuan 2 rata-rata nilai kelas adalah 2,68 dan pertemuan 3 nilai rata-rata kelas adalah 3,1. Jadi dari pertemuan 1 ke pertemuan 3 mengalami kenaikan rata-rata sebanyak 8,2. Pada penilaian psikomotorik aspek mengkomunikasikan adalah aspek yang paling menonjol karena disini aspek mengkomunikasikan mengalamai kenaikan skor perolehan yang didapat pada setiap pertemuannya yaitu pada pertemuan 1 skor yang diperoleh aspek mengkomunikasikan yaitu 48, sedangkan pada pertemuan ke 2 skor yang diperoleh mengalami peningkatan menjadi 51 hingga pada pertemuan ke 3 aspek mengkomunikasikan memperoleh skor sebesar 59. Jadi dapat disimpulkan aspek mengkomunikasikan mengalami peningkatan pada setiap pertemuannya. Berdasarkan data nilai psikomotorik mengalami peningkatan yang signifikan pada setiap pembelajaran. 
Berdasarkan data yang diperoleh dapat disimpulkan bahwa perlakuan dengan menggunakan model Snowball Throwing berbantu media Wayang Kertas efektif dalam meningkatkan hasil belajar siswa baik dalam kognitif, afektif, dan psikhomotorik kelas IV SD Negeri 2 Kuwu tahun ajaran 2018/2019. Penelitian dilakukan untuk mengatahui keefektifan model Snowball Throwing berbantu media Wayang Kertas, analisi data menggunkana uji t ,diperoleh hasil uji t sebagai berikut :

Tabel 6 Tabel Perhitungan uji-t

\begin{tabular}{lll}
\hline & Pretest & Posttest \\
\hline Rata-rata & 66,4 & 75,4 \\
$\mathrm{~N}$ & 19 & 19 \\
\hline $\mathrm{Md}$ & 7,789 & \\
\hline $\mathrm{T}_{\text {hitung }}$ & 14,466 & \\
\hline $\mathrm{T}_{\text {tabel }}$ & 2,026 & \\
\hline Keterangan & $\mathrm{H}_{0}$ ditolak dan $\mathrm{H}_{\mathrm{a}}$ diterima & \\
\hline
\end{tabular}

Dari hasil perhitungan diperoleh thitung $=14,466$. Kemudian dibandingkan dengan harga $t_{\text {tabel }}$ pada $\mathrm{db}=37$ (dari rumus $\mathrm{db}=\mathrm{n}+\mathrm{n}-1=19+19-1=37$ ) dan taraf signifansi $=0,05$ $(5 \%)$ di peroleh nilai $t_{\text {tabel }}=2,026$ dan nilai $t_{\text {hitung }}=14,466$. Dengan kriteria pengujian hipotesis diterima jika nilai $t_{\text {hitung }}>t_{\text {tabel }}$. Karena pada perhitungan uji $t$ di peroleh nilai $t_{\text {hitung }}>t_{\text {tabel }}$ yaitu. Maka hipotesis $\left(\mathrm{H}_{\mathrm{a}}\right)$ yang diajukan dapat di terima. Dengan demikian dapat disimpulkan bahwa model pembelajaran Snowball Throwing berbantu media Wayang Kertas menunjukan adanya perbedaan rata-rata hasil belajar tema Indahnya Keragaman Di Negriku subtema Keragaman Suku Bangsa Dan Agama Di Negeriku siswa kelas IV SD Negeri 2 Kuwu.

Tabel 7 Nilai Ketuntasan Siswa

\begin{tabular}{|c|c|c|c|c|}
\hline & \multicolumn{2}{|r|}{ Pretest } & \multicolumn{2}{|r|}{ Posttest } \\
\hline & Nilai & Ketuntasan & Nilai & Ketuntasan \\
\hline & 83 & Tuntas & 93 & Tuntas \\
\hline & 43 & Belum Tuntas & 53 & Belum Tuntas \\
\hline Nilai Tertinggi & & 83 & & 93 \\
\hline Nilai Terendah & & 43 & & 53 \\
\hline Mean & & 67,31 & & 75,10 \\
\hline Modus & & 76 & & 93 \\
\hline Median & & 66 & & 73 \\
\hline KKM & & 68 & & 68 \\
\hline Jumlah Siswa Tuntas & & 9 & & 13 \\
\hline Jumlah Siswa Tidak tuntas & & 10 & & 9 \\
\hline Presentase Ketuntasan & & $100 \%$ & & \\
\hline
\end{tabular}

Uji ketuntasan individu yang dimaksud dalam penelitian ini yaitu apabila nilai posttest siswa dapat melebihi atau sama dengan nilai KKM yaitu 68, maka siswa dikatakan tuntas. Berdasarkan Tabel 7 tersebut diperoleh rata-rata hasil belajar Pretest dan Posttets pada tema 7 subtema 1 (Keragaman suku dan Agama di Negeriku) siswa kelas IV SD Negeri 2 Kuwu mengalami peningkatan. Rata-rata nilai pretest siswa sebesar 67,31 dan rata-rata nilai posttest siswa mengalami peningkatan yaitu sebesar 75,10. Maka dapat disimpulkan bahwa rata-rata hasil belajar siswa setelah diberi perlakuan dengan menggunakan model Snowball Throwing berbantu Media Wayang Kertas $\geq \mathrm{KKM}$, sehingga $\mathrm{H}_{\mathrm{a}}$ diterima. Artinya model pembelajaran Snowball Throwing berbantu Media Wayang Kertas efektif terhadap hasil belajar siswa kelas IV SD Negeri 2 Kuwu. 


\section{Simpulan dan Saran}

Berdasarkan hasil penelitian yang telah dilakukan dapat disimpulkan bahwa model Snwoball Throwing berbantu media Wayang Kertas efektif untuk meningkatkan hasil belajar subtema Indahnya Keragaman Budaya Dan Agama Di Negriku siswa kelas IV SD Negeri 2 Kuwu. Hal ini berdasarkan analisis data hasil penelitian dengan menggunakan uji-t yang diperoleh $t_{\text {hitung }}=14,466$ dengan taraf signifikan $5 \%$ didapat nilai $t_{\text {tabel }}=2,101$. Karena $t_{\text {hitung }}(14,466)>t_{\text {tabel }}(2,101)$ maka data hipotesis diterima dan berdistribusi normal. Dan pada uji normalitas nilai hasil belajar siswa mengalami peningkatan yaitu dibuktikan dalam nilai rata-rata kelas untuk pretest sebesar 66,4 dan posttest sebesar 75,4.

Berdasarkan hasil penelitian yang diperoleh, agar proses pembelajaran dapat memberikan hasil yang maksimal maka peneliti menyampaikan saran sebagai berikut: 1) Model Snowball Throwing berbantu media Wayang Kertas dapat dijadikan sebagai alternatif guru dalam pengejaran di kelas, karena dapat memberikan wawasan pengetahuan tentang model pembelajaran yang dapat meningkatkan pemahaman siswa. 2) Model pembelajaran Snowball Throwing berbantu media Wayang Kertas dapat dimanfaatkan oleh siswa untuk meningkatkan hasil belajar, karena siswa menjadi aktif dalam mengikuti pembelajaran sehingga dapat menumbuhkan pola pikir siswa yang kreatif dan kritis dalam menemukan ide, serta dapat memotivasi siswa untuk semangat belajar. 3) Model pembelajaran Snowball Trowing berbantu media Wayang Kertas dapat dimanfaatkan oleh sekolah untuk menambah pengetahuan bagi guru-guru SD Negeri 2 Kuwu tentang model Snowball Throwing memberi kontribusi yang lebih baik dalam perbaikan pembelajaran, sehingga mutu sekolah meningkat.

\section{Daftar Rujukan}

Ahmad Susanto. 2013. Teori Belajar dan Pembelajaran di Sekolah Dasar. Jakarta : Kencana Prenadamedia Group

A.H Hujair Sanaky. 2009. Media Pembelajaran. Yogyakarta: Safira Insania Press.

Dahar, Ratna Wilis. 2011. Teori teori Belajar dan Pembelajaran. Jakarta : Erlangga

Daryanto. 2013. Media Pembelajaran Perannya Sangat Penting Dalam Mencapai Tujuan Pembelajaran. Yoyjakarta: Gava Media.

Hamdaya, Jumanta. 2015. Model dan Metode Pembelajaran Kreatif dan Berkarakter. Bogor: Ghalia Indonesia

Parwati Ni Nyoman, I Putu Pasek Suryawan, Ratih Ayu Apsari. 2018. Belajar dan Pembelajaran. Jakarta: Raja Grafindo Persada.

Prastowo, Andi. 2013. Pengembangan Bahan Ajar Tematik. Yogyakarta. Diva Press

Schunk, D.H. 2012. Teori-teori Pembelajaran Perspektif Pendidikan. Yogyakarta: Pustaka Pelajar.

Shoimin, Aris. 2014. Enam Puluh Delapan Model Pembelajaran INOVATIF dalam Kurikulum 2013. Yogyakarta: AR-RUZZ MEDIA.

Sugiyono. 2017. Metode Penelitian Kualitatif, Kuantitatif, dan R\&D. Bandung: Afabeta, CV.

Trianto. 2013. Desain Pengembangan Pembelajaran Tematik Bagi Anak Usia Dini, TK/RA \& Anak Usia Kelas Awal SD/MI. Jakarta: Kencana. 
Oktavianti, Rizki. Wijayanto, Agus. 2014. "Pengembangan Media Gayanghetum (Gambar Wayang Hewan Dan Tumbuhan) Dalam Pembelajaran Tematik Terintregasi Kelas IV SD. Mimbar Sekolah Dasar, Vol.1, No.1, hlm.65. Program Studi PGSD IKIP PGRI Semarang.

Ramlah. 2017. Penerapan Metode Pembelajaran Kooperatif Tipe Snowball Throwing untuk Meningkatkan Hasil Belajar Fisika Pada Siswa Kelas Xii Sman 9 Pekanbaru. Jurnal Pendidikan dan Pengajaran Program Studi Pendidikan Guru Sekolah Dasar FKIP Universitas Riau Volume 1 Nomor 1 Juli 2017

Siti, Irsanti. 2018. "Keefektifan Metode Bercerita berbantuan Media Wayang Kertas Terhadap Hasil Belajar Dalam pembelajaran Tematik Peserta Didik Kelas III SD N Peterongan Semarang". Skripsi. Univeristas PGRI Semarang.

Undang-undang Nomor 20 Tahun 2003 Tentang Sistem Pendiidkan Nasional.2004.Jakarta: bab 4, pasal 5

Yuliati.2015. Efektifitas Penggunaan Model Kooperatif Tipe Snowball Throwing Untuk Meningkatkan Hasil Belajar Siswa pada Materi Sistem Pertidaksamaan Linear di Kelas XI-IS-2 Sma Negeri 7 Banda Aceh. Jurnal Peluang, Volume 3, Nomor 2, April 2015, ISSN: 2302-5158 